Research Report 1679

\title{
An Initial Evaluation of a Simulation-Based Training Program for Army National Guard Units
}

\author{
Theodore M. Shlechter and David W. Bessemer
}

U.S. Army Research Institute

Paul Nesselroade, Jr., and James Anthony

University of Louisville

\author{
Armed Forces Research Unit \\ Barbara A. Black, Chief \\ Training Systems Research Division \\ Jack H. Hiller, Director
}

U.S. Army Research Institute for the Behavioral and Social Sciences

5001 Eisenhower Avenue, Alexandria, Virginia 22333-5600

Office, Deputy Chief of Staff for Personnel

Department of the Army

June 1995 